\title{
Melanocortin receptors (version 2019.4) in the IUPHAR/BPS Guide to Pharmacology Database
}

\author{
Vanni Caruso ${ }^{1}$, Biao-Xin Chai ${ }^{2}$, Adrian J. L. Clark ${ }^{3}$, Roger D. Cone ${ }^{2}$, Alex N. Eberle ${ }^{4}$, Sadaf Farooqi ${ }^{5}$, Tung M. \\ Fong $^{6}$, Ira Gantz ${ }^{7}$, Carrie Haskell-Luevano ${ }^{8}$, Victor J. Hruby ${ }^{9}$, Kathleen G. Mountjoy ${ }^{10}$, Colin Pouton ${ }^{11}$, Helgi \\ Schiöth $^{12}$, Jeffrey B. Tatro ${ }^{13}$ and Jarl E. S. Wikberg ${ }^{12}$ \\ 1. University of Tasmania, Australia \\ 2. University of Michigan, USA \\ 3. St. Bartholomew's Hospital, UK \\ 4. Universitsspital, Switzerland \\ 5. University of Cambridge, UK \\ 6. Covance Inc, USA \\ 7. Merck \& Co. Inc., USA \\ 8. University of Minnesota, USA \\ 9. University of Arizona, USA \\ 10. University of Auckland, New Zealand \\ 11. University of Bath, UK \\ 12. Uppsala University, Sweden \\ 13. New England Medical Center Hospital, USA
}

\begin{abstract}
Melanocortin receptors (provisional nomenclature as recommended by NC-IUPHAR [36]) are activated by members of the melanocortin family ( $\alpha-\mathrm{MSH}, \beta-\mathrm{MSH}$ and $\gamma-\mathrm{MSH}$ forms; $\delta$ form is not found in mammals) and adrenocorticotrophin (ACTH). Endogenous antagonists include agouti and agouti-related protein. ACTH(1-24) was approved by the US FDA as a diagnostic agent for adrenal function test, whilst NDP-MSH was approved by EMA for the treatment of erythropoietic protoporphyria. Several synthetic melanocortin receptor agonists are under clinical development.
\end{abstract}

\section{Contents}

This is a citation summary for Melanocortin receptors in the Guide to Pharmacology database (GtoPdb). It exists purely as an adjunct to the database to facilitate the recognition of citations to and from the database by citation analyzers. Readers will almost certainly want to visit the relevant sections of the database which are given here under database links.

GtoPdb is an expert-driven guide to pharmacological targets and the substances that act on them. GtoPdb is a reference work which is most usefully represented as an on-line database. As in any publication this work should be appropriately cited, and the papers it cites should also be recognized. This document provides a citation for the relevant parts of the database, and also provides a reference list for the research cited by those parts. 
Please note that the database version for the citations given in GtoPdb are to the most recent preceding version in which the family or its subfamilies and targets were substantially changed. The links below are to the current version. If you need to consult the cited version, rather than the most recent version, please contact the GtoPdb curators.

\section{Database links}

Melanocortin receptors

http://www.guidetopharmacology.org/GRAC/FamilyDisplayForward?familyld=38

Introduction to Melanocortin receptors

http://www.guidetopharmacology.org/GRAC/FamilyIntroductionForward?familyld=38

Receptors

$\mathrm{MC}_{1}$ receptor

http://www.guidetopharmacology.org/GRAC/ObjectDisplayForward?objectld=282

$\mathrm{MC}_{2}$ receptor

http://www.guidetopharmacology.org/GRAC/ObjectDisplayForward?objectld=283

$\mathrm{MC}_{3}$ receptor

http://www.guidetopharmacology.org/GRAC/ObjectDisplayForward?objectld=284

$\mathrm{MC}_{4}$ receptor

http://www.guidetopharmacology.org/GRAC/ObjectDisplayForward?objectld=285

$\mathrm{MC}_{5}$ receptor

http://www.guidetopharmacology.org/GRAC/ObjectDisplayForward?objectld=286

\section{References}

1. Adan RA, Szklarczyk AW, Oosterom J, Brakkee JH, Nijenhuis WA, Schaaper WM, Meloen RH and Gispen WH. (1999) Characterization of melanocortin receptor ligands on cloned brain melanocortin receptors and on grooming behavior in the rat. Eur J Pharmaco/378: 249-258 [PMID:10493100]

2. Al-Obeidi F, Hruby VJ, Castrucci AM and Hadley ME. (1989) Design of potent linear $\alpha$-melanotropin 4-10 analogues modified in positions 5 and 10. J Med Chem. 32: 174-179 [PMID:2535874]

3. Argiolas A and Melis MR. (2013) Neuropeptides and central control of sexual behaviour from the past to the present: a review. Prog. Neurobiol. 108: 80-107 [PMID:23851261]

4. Balse-Srinivasan P, Grieco P, Cai M, Trivedi D and Hruby VJ. (2003) Structure-activity relationships of novel cyclic alpha-MSH/beta-MSH hybrid analogues that lead to potent and selective ligands for the human MC3R and human MC5R. J. Med. Chem. 46: 3728-33 [PMID:12904077]

5. Bednarek MA, MacNeil T, Kalyani RN, Tang R, Van der Ploeg LH and Weinberg DH. (2001) Selective, high affinity peptide antagonists of alpha-melanotropin action at human melanocortin receptor 4: their synthesis and biological evaluation in vitro. J. Med. Chem. 44: 3665-72 [PMID:11606131]

6. Benoit SC, Schwartz MW, Lachey JL, Hagan MM, Rushing PA, Blake KA, Yagaloff KA, Kurylko G, Franco $L$ and Danhoo W et al.. (2000) A novel selective melanocortin-4 receptor agonist reduces food intake in rats and mice without producing aversive consequences. J. Neurosci. 20: 3442-8 [PMID:10777807]

7. Bertolini A, Tacchi R and Vergoni AV. (2009) Brain effects of melanocortins.Pharmacol. Res. 59: 13-47 [PMID:18996199]

8. Borowsky B, Durkin MM, Ogozalek K, Marzabadi MR, DeLeon J, Lagu B, Heurich R, Lichtblau H, Shaposhnik Z, Daniewska I, Blackburn TP, Branchek TA, Gerald C, Vaysse PJ and Forray C. (2002) Antidepressant, anxiolytic and anorectic effects of a melanin-concentrating hormone-1 receptor antagonist. Nat Med 8: 825-830 [PMID:12118247]

9. Boston BA and Cone RD. (1996) Characterization of melanocortin receptor subtype expression in murine adipose tissues and in the 3T3-L1 cell line. Endocrinology 137: 2043-50 [PMID:8612546]

10. Butler AA, Kesterson RA, Khong K, Cullen MJ, Pelleymounter MA, Dekoning J, Baetscher M and Cone RD. (2000) A unique metabolic syndrome causes obesity in the melanocortin-3 receptor-deficient mouse. 
Endocrinology 141: 3518-21 [PMID:10965927]

11. Böhm M, Eickelmann M, Li Z, Schneider SW, Oji V, Diederichs S, Barsh GS, Vogt A, Stieler K and BlumePeytavi $U$ et al.. (2005) Detection of functionally active melanocortin receptors and evidence for an immunoregulatory activity of alpha-melanocyte-stimulating hormone in human dermal papilla cells. Endocrinology 146: 4635-46 [PMID:16081629]

12. Carla Caruso, L. C., Daniela Durand and Teresa N. Scimonelli and Mercedes Lasaga. (2012) Melanocortins: Anti-Inflammatory and Neuroprotective Peptides In Neurodegeneration Edited by L. Miguel Martins: InTech:

13. Caruso V, Lagerström MC, Olszewski PK, Fredriksson R and Schiöth HB. (2014) Synaptic changes induced by melanocortin signalling. Nat. Rev. Neurosci. 15: 98-110 [PMID:24588018]

14. Castrucci AM, Hadley ME and Hruby VJ. (1984) Melanotropin bioassays: in vitro and in vivo comparisons. Gen. Comp. Endocrinol. 55: 104-11 [PMID:6611282]

15. Catania A, Rajora N, Capsoni F, Minonzio F, Star RA and Lipton JM. (1996) The neuropeptide alpha-MSH has specific receptors on neutrophils and reduces chemotaxis in vitro. Peptides 17: 675-9 [PMID:8804079]

16. Chagnon YC, Chen WJ, Pérusse L, Chagnon M, Nadeau A, Wilkison WO and Bouchard C. (1997) Linkage and association studies between the melanocortin receptors 4 and 5 genes and obesity-related phenotypes in the Québec Family Study. Mol. Med. 3: 663-73 [PMID:9392003]

17. Chaki S, Funakoshi T, Hirota-Okuno S, Nishiguchi M, Shimazaki T, lijima M, Grottick AJ, Kanuma K, Omodera K, Sekiguchi Y, Okuyama S, Tran TA, Semple G and Thomsen W. (2005) Anxiolytic- and antidepressant-like profile of ATC0065 and ATC0175: nonpeptidic and orally active melanin-concentrating hormone receptor 1 antagonists. $J$ Pharmacol Exp Ther 313: 831-839 [PMID:15677346]

18. Chaki S, Hirota S, Funakoshi T, Suzuki Y, Suetake S, Okubo T, Ishii T, Nakazato A and Okuyama S. (2003) Anxiolytic-like and antidepressant-like activities of MCL0129 (1-[(S)-2-(4-fluorophenyl)-2-(4isopropylpiperadin-1-yl)ethyl]-4-[4-(2-methoxynaphthalen-1-yl)butyl]piperazine), a novel and potent nonpeptide antagonist of the melanocortin-4 receptor. J. Pharmacol. Exp. Ther. 304: 818-26 [PMID:12538838]

19. Chen AS, Marsh DJ, Trumbauer ME, Frazier EG, Guan XM, Yu H, Rosenblum Cl, Vongs A, Feng Y and Cao $L$ et al.. (2000) Inactivation of the mouse melanocortin-3 receptor results in increased fat mass and reduced lean body mass. Nat. Genet. 26: 97-102 [PMID:10973258]

20. Chen W, Kelly MA, Opitz-Araya X, Thomas RE, Low MJ and Cone RD. (1997) Exocrine gland dysfunction in MC5-R-deficient mice: evidence for coordinated regulation of exocrine gland function by melanocortin peptides. Cell 91: 789-98 [PMID:9413988]

21. Chhajlani V. (1996) Distribution of cDNA for melanocortin receptor subtypes in human tissues.Biochem. Mol. Biol. Int. 38: 73-80 [PMID:8932521]

22. Chhajlani V, Muceniece R and Wikberg JE. (1993) Molecular cloning of a novel human melanocortin receptor. Biochem. Biophys. Res. Commun. 195: 866-73 [PMID:8396929]

23. Chhajlani $V$ and Wikberg JE. (1996) Molecular cloning and expression of the human melanocyte stimulating hormone receptor cDNA (FEBS 11553). FEBS Lett. 390: 238 [PMID:8706868]

24. Chu H, Xia J, Yang Z and Gao J. (2012) Melanocortin 4 receptor induces hyperalgesia and allodynia after chronic constriction injury by activation of p38 MAPK in DRG. Int. J. Neurosci. 122: 74-81 [PMID:21985621]

25. Clark AJ, McLoughlin L and Grossman A. (1993) Familial glucocorticoid deficiency associated with point mutation in the adrenocorticotropin receptor. Lancet 341: 461-2 [PMID:8094489]

26. Cone RD. (2005) Anatomy and regulation of the central melanocortin system.Nat. Neurosci. 8: 571-8 [PMID:15856065]

27. Cone RD, Lu D, Koppula S, Vage DI, Klungland H, Boston B, Chen W, Orth DN, Pouton C and Kesterson RA. (1996) The melanocortin receptors: agonists, antagonists, and the hormonal control of pigmentation. Recent Prog. Horm. Res. 51: 287-317; discussion 318 [PMID:8701084]

28. da Silva AA, do Carmo JM, Wang Z and Hall JE. (2014) The brain melanocortin system, sympathetic control, and obesity hypertension. Physiology (Bethesda) 29: 196-202 [PMID:24789984] 
29. Daniels D, Suzuki A, Shapiro E, Luo L, Yee DK and Fluharty SJ. (2005) Rattus norvegicus melanocortin 3 receptor: a corrected sequence. Peptides 26: 1835-41 [PMID:15985309]

30. Desarnaud F, Labbe O, Eggerickx D, Vassart G and Parmentier M. (1994) Molecular cloning, functional expression and pharmacological characterization of a mouse melanocortin receptor gene. Biochem. J. 299 ( Pt 2): 367-73 [PMID:8172596]

31. Dinulescu DM and Cone RD. (2000) Agouti and agouti-related protein: analogies and contrasts.J. Biol. Chem. 275: 6695-8 [PMID:10702221]

32. Fan W, Boston BA, Kesterson RA, Hruby VJ and Cone RD. (1997) Role of melanocortinergic neurons in feeding and the agouti obesity syndrome. Nature 385: 165-8 [PMID:8990120]

33. Farooqi IS, Keogh JM, Yeo GS, Lank EJ, Cheetham T and O'Rahilly S. (2003) Clinical spectrum of obesity and mutations in the melanocortin 4 receptor gene. N. Engl. J. Med. 348: 1085-95 [PMID:12646665]

34. Farooqi IS and O'Rahilly S. (2008) Mutations in ligands and receptors of the leptin-melanocortin pathway that lead to obesity. Nat Clin Pract Endocrinol Metab 4: 569-77 [PMID:18779842]

35. Fong TM, Mao C, MacNeil T, Kalyani R, Smith T, Weinberg D, Tota MR and Van der Ploeg LH. (1997) ART (protein product of agouti-related transcript) as an antagonist of MC-3 and MC-4 receptors. Biochem. Biophys. Res. Commun. 237: 629-31 [PMID:9299416]

36. Foord SM, Bonner TI, Neubig RR, Rosser EM, Pin JP, Davenport AP, Spedding M and Harmar AJ. (2005) International Union of Pharmacology. XLVI. G protein-coupled receptor list. Pharmacol. Rev. 57: 279-88 [PMID:15914470]

37. Gantz I and Fong TM. (2003) The melanocortin system. Am. J. Physiol. Endocrinol. Metab. 284: E468-74 [PMID:12556347]

38. Gantz I, Konda Y, Tashiro T, Shimoto Y, Miwa H, Munzert G, Watson SJ, DelValle J and Yamada T. (1993) Molecular cloning of a novel melanocortin receptor. J. Biol. Chem. 268: 8246-50 [PMID:8463333]

39. Gantz I, Miwa H, Konda Y, Shimoto Y, Tashiro T, Watson SJ, DelValle J and Yamada T. (1993) Molecular cloning, expression, and gene localization of a fourth melanocortin receptor. J. Biol. Chem. 268: 15174-9 [PMID:8392067]

40. Gantz I, Shimoto Y, Konda Y, Miwa H, Dickinson CJ and Yamada T. (1994) Molecular cloning, expression, and characterization of a fifth melanocortin receptor. Biochem. Biophys. Res. Commun. 200: 1214-20 [PMID:8185570]

41. Ghamari-Langroudi M, Digby GJ, Sebag JA, Millhauser GL, Palomino R, Matthews R, Gillyard T, Panaro BL, Tough IR and Cox HM et al.. (2015) G-protein-independent coupling of MC4R to Kir7.1 in hypothalamic neurons. Nature 520: 94-8 [PMID:25600267]

42. Giuliani D, Mioni C, Altavilla D, Leone S, Bazzani C, Minutoli L, Bitto A, Cainazzo MM, Marini H and Zaffe $D$ et al.. (2006) Both early and delayed treatment with melanocortin 4 receptor-stimulating melanocortins produces neuroprotection in cerebral ischemia. Endocrinology 147: 1126-35 [PMID:16254026]

43. Grieco P, Balse PM, Weinberg D, MacNeil T and Hruby VJ. (2000) D-Amino acid scan of gammamelanocyte-stimulating hormone: importance of $\operatorname{Trp}(8)$ on human MC3 receptor selectivity. J. Med. Chem. 43: 4998-5002 [PMID:11150170]

44. Grieco P, Cai M, Han G, Trivedi D, Campiglia P, Novellino E and Hruby VJ. (2007) Further structureactivity studies of lactam derivatives of MT-II and SHU-9119: their activity and selectivity at human melanocortin receptors 3, 4, and 5. Peptides 28: 1191-6 [PMID:17482720]

45. Grieco P, Lavecchia A, Cai M, Trivedi D, Weinberg D, MacNeil T, Van der Ploeg LH and Hruby VJ. (2002) Structure-activity studies of the melanocortin peptides: discovery of potent and selective affinity antagonists for the hMC3 and hMC4 receptors. J. Med. Chem. 45: 5287-94 [PMID:12431055]

46. Griffon N, Mignon V, Facchinetti P, Diaz J, Schwartz JC and Sokoloff P. (1994) Molecular cloning and characterization of the rat fifth melanocortin receptor. Biochem. Biophys. Res. Commun. 200: 1007-14 [PMID:8179577]

47. Hartmeyer M, Scholzen T, Becher E, Bhardwaj RS, Schwarz T and Luger TA. (1997) Human dermal microvascular endothelial cells express the melanocortin receptor type 1 and produce increased levels of IL-8 upon stimulation with alpha-melanocyte-stimulating hormone. J. Immunol. 159: 1930-7 
[PMID:9257858]

48. Herpin TF, Yu G, Carlson KE, Morton GC, Wu X, Kang L, Tuerdi H, Khanna A, Tokarski JS and Lawrence RM et al.. (2003) Discovery of tyrosine-based potent and selective melanocortin-1 receptor small-molecule agonists with anti-inflammatory properties. J. Med. Chem. 46: 1123-6 [PMID:12646021]

49. Hruby VJ, Lu D, Sharma SD, Castrucci AL, Kesterson RA, al-Obeidi FA, Hadley ME and Cone RD. (1995) Cyclic lactam alpha-melanotropin analogues of Ac-Nle4-cyclo[Asp5, D-Phe7,Lys10] alpha-melanocytestimulating hormone-(4-10)-NH2 with bulky aromatic amino acids at position 7 show high antagonist potency and selectivity at specific melanocortin receptors. J. Med. Chem. 38: 3454-61 [PMID:7658432]

50. Huang RR, Singh G, Van der Ploeg LH and Fong TM. (2000) Species-dependent pharmacological properties of the melanocortin-5 receptor. J. Recept. Signal Transduct. Res. 20: 47-59 [PMID:10711496]

51. Huszar D, Lynch CA, Fairchild-Huntress V, Dunmore JH, Fang Q, Berkemeier LR, Gu W, Kesterson RA, Boston BA and Cone RD et al.. (1997) Targeted disruption of the melanocortin-4 receptor results in obesity in mice. Cell 88: 131-41 [PMID:9019399]

52. Jayawickreme CK, Jayawickreme SP and Lerner MR. (1998) Generation of multiuse peptide libraries for functional screenings. Methods Mol. Biol. 87: 107-18 [PMID:9523265]

53. Kapas S, Cammas FM, Hinson JP and Clark AJ. (1996) Agonist and receptor binding properties of adrenocorticotropin peptides using the cloned mouse adrenocorticotropin receptor expressed in a stably transfected HeLa cell line. Endocrinology 137: 3291-4 [PMID:8754753]

54. Kask A, Mutulis F, Muceniece R, Pähkla R, Mutule I, Wikberg JE, Rägo L and Schiöth HB. (1998) Discovery of a novel superpotent and selective melanocortin-4 receptor antagonist (HS024): evaluation in vitro and in vivo. Endocrinology 139: 5006-14 [PMID:9832440]

55. Kiefer LL, Veal JM, Mountjoy KG and Wilkison WO. (1998) Melanocortin receptor binding determinants in the agouti protein. Biochemistry 37: 991-7 [PMID:9454589]

56. Kievit P, Halem H, Marks DL, Dong JZ, Glavas MM, Sinnayah P, Pranger L, Cowley MA, Grove KL and Culler MD. (2013) Chronic treatment with a melanocortin-4 receptor agonist causes weight loss, reduces insulin resistance, and improves cardiovascular function in diet-induced obese rhesus macaques. Diabetes 62: 490-7 [PMID:23048186]

57. Kishi T, Aschkenasi CJ, Lee CE, Mountjoy KG, Saper CB and Elmquist JK. (2003) Expression of melanocortin 4 receptor mRNA in the central nervous system of the rat. J. Comp. Neurol. 457: 213-35 [PMID:12541307]

58. Koch M and Horvath TL. (2014) Molecular and cellular regulation of hypothalamic melanocortin neurons controlling food intake and energy metabolism. Mol. Psychiatry 19: 752-61 [PMID:24732669]

59. Kojima I, Kojima K and Rasmussen H. (1985) Role of calcium and cAMP in the action of adrenocorticotropin on aldosterone secretion. J. Biol. Chem. 260: 4248-56 [PMID:2579947]

60. Kopanchuk S, Veiksina S, Petrovska R, Mutule I, Szardenings M, Rinken A and Wikberg JE. (2005) Cooperative regulation of ligand binding to melanocortin receptor subtypes: evidence for interacting binding sites. Eur. J. Pharmacol. 512: 85-95 [PMID:15840392]

61. Krishna R, Gumbiner B, Stevens C, Musser B, Mallick M, Suryawanshi S, Maganti L, Zhu H, Han TH and Scherer $L$ et al.. (2009) Potent and selective agonism of the melanocortin receptor 4 with MK-0493 does not induce weight loss in obese human subjects: energy intake predicts lack of weight loss efficacy. Clin. Pharmacol. Ther. 86: 659-66 [PMID:19741604]

62. Kubo M, Ishizuka T, Kijima H, Kakinuma M and Koike T. (1995) Cloning of a mouse adrenocorticotropin receptor-encoding gene. Gene 153: 279-80 [PMID:7875603]

63. Kumar KG, Sutton GM, Dong JZ, Roubert P, Plas P, Halem HA, Culler MD, Yang H, Dixit VD and Butler AA. (2009) Analysis of the therapeutic functions of novel melanocortin receptor agonists in MC3R-and MC4R-deficient C57BL/6J mice. Peptides 30: 1892-900 [PMID:19646498]

64. Labbe O, Desarnaud F, Eggerickx D, Vassart G and Parmentier M. (1994) Molecular cloning of a mouse melanocortin 5 receptor gene widely expressed in peripheral tissues. Biochemistry 33: 4543-4549 [PMID:8161509]

65. Lim BK, Huang KW, Grueter BA, Rothwell PE and Malenka RC. (2012) Anhedonia requires MC4R- 
mediated synaptic adaptations in nucleus accumbens. Nature 487: 183-9 [PMID:22785313]

66. Lu D, Willard D, Patel IR, Kadwell S, Overton L, Kost T, Luther M, Chen W, Woychik RP and Wilkison WO et al.. (1994) Agouti protein is an antagonist of the melanocyte-stimulating-hormone receptor.Nature 371: 799-802 [PMID:7935841]

67. MacNeil DJ, Howard AD, Guan X, Fong TM, Nargund RP, Bednarek MA, Goulet MT, Weinberg DH, Strack AM and Marsh DJ et al.. (2002) The role of melanocortins in body weight regulation: opportunities for the treatment of obesity. Eur. J. Pharmacol. 440: 141-57 [PMID:12007532]

68. Mansour AR, Farmer MA, Baliki MN and Apkarian AV. (2014) Chronic pain: the role of learning and brain plasticity. Restor. Neurol. Neurosci. 32: 129-39 [PMID:23603439]

69. Mountjoy KG. (2015) Pro-Opiomelanocortin (POMC) Neurones, POMC-Derived Peptides, Melanocortin Receptors and Obesity: How Understanding of this System has Changed Over the Last Decade. J. Neuroendocrinol. 27: 406-18 [PMID:25872650]

70. Mountjoy KG, Bird IM, Rainey WE and Cone RD. (1994) ACTH induces up-regulation of ACTH receptor mRNA in mouse and human adrenocortical cell lines. Mol. Cell. Endocrinol. 99: R17-20 [PMID:8187950]

71. Mountjoy KG, Kong PL, Taylor JA, Willard DH and Wilkison WO. (2001) Melanocortin receptor-mediated mobilization of intracellular free calcium in HEK293 cells. Physiol. Genomics 5: 11-9 [PMID:11161002]

72. Mountjoy KG, Mortrud MT, Low MJ, Simerly RB and Cone RD. (1994) Localization of the melanocortin-4 receptor (MC4-R) in neuroendocrine and autonomic control circuits in the brain. Mol. Endocrinol. 8: 1298308 [PMID:7854347]

73. Mountjoy KG, Robbins LS, Mortrud MT and Cone RD. (1992) The cloning of a family of genes that encode the melanocortin receptors. Science 257: 1248-51 [PMID:1325670]

74. Mountjoy KG and Wild JM. (1998) Melanocortin-4 receptor mRNA expression in the developing autonomic and central nervous systems. Brain Res. Dev. Brain Res. 107: 309-14 [PMID:9593962]

75. Nakanishi S, Inoue A, Kita T, Nakamura M, Chang AC, Cohen SN and Numa S. (1979) Nucleotide sequence of cloned cDNA for bovine corticotropin-beta-lipotropin precursor. Nature 278: 423-7 [PMID:221818]

76. Naville D, Barjhoux L, Jaillard C, Saez JM, Durand P and Bégeot M. (1997) Stable expression of normal and mutant human ACTH receptor: study of ACTH binding and coupling to adenylate cyclase. Mol. Cell. Endocrinol. 129: 83-90 [PMID:9175632]

77. Ni XP, Pearce D, Butler AA, Cone RD and Humphreys MH. (2003) Genetic disruption of gammamelanocyte-stimulating hormone signaling leads to salt-sensitive hypertension in the mouse. J. Clin. Invest. 111: 1251-8 [PMID:12697744]

78. Nickolls SA, Cismowski MI, Wang X, Wolff M, Conlon PJ and Maki RA. (2003) Molecular determinants of melanocortin 4 receptor ligand binding and MC4/MC3 receptor selectivity. J. Pharmacol. Exp. Ther. 304: 1217-27 [PMID:12604699]

79. Norman D, Isidori AM, Frajese V, Caprio M, Chew SL, Grossman AB, Clark AJ, Michael Besser G and Fabbri A. (2003) ACTH and alpha-MSH inhibit leptin expression and secretion in 3T3-L1 adipocytes: model for a central-peripheral melanocortin-leptin pathway. Mol. Cell. Endocrinol. 200: 99-109 [PMID:12644303]

80. Ollmann MM, Wilson BD, Yang YK, Kerns JA, Chen Y, Gantz I and Barsh GS. (1997) Antagonism of central melanocortin receptors in vitro and in vivo by agouti-related protein. Science 278: 135-8 [PMID:9311920]

81. Oosterom J, Nijenhuis WA, Schaaper WM, Slootstra J, Meloen RH, Gispen WH, Burbach JP and Adan RA. (1999) Conformation of the core sequence in melanocortin peptides directs selectivity for the melanocortin MC3 and MC4 receptors. J. Biol. Chem. 274: 16853-60 [PMID:10358030]

82. Pandit R, van der Zwaal EM, Luijendijk MC, Brans MA, van Rozen AJ, Oude Ophuis RJ, Vanderschuren LJ, Adan RA and la Fleur SE. (2015) Central melanocortins regulate the motivation for sucrose reward. PLoS ONE 10: e0121768 [PMID:25811380]

83. Rached M, El Mourabit H, Buronfosse A, Blondet A, Naville D, Begeot M and Penhoat A. (2005) Expression of the human melanocortin-2 receptor in different eukaryotic cells. Peptides 26: 1842-7 
[PMID:15982783]

84. Robbins LS, Nadeau JH, Johnson KR, Kelly MA, Roselli-Rehfuss L, Baack E, Mountjoy KG and Cone RD. (1993) Pigmentation phenotypes of variant extension locus alleles result from point mutations that alter MSH receptor function. Cell 72: 827-34 [PMID:8458079]

85. Roselli-Rehfuss L, Mountjoy KG, Robbins LS, Mortrud MT, Low MJ, Tatro JB, Entwistle ML, Simerly RB and Cone RD. (1993) Identification of a receptor for gamma melanotropin and other proopiomelanocortin peptides in the hypothalamus and limbic system. Proc. Natl. Acad. Sci. U.S.A. 90: 8856-60 [PMID:8415620]

86. Rosenfeld RD, Zeni L, Welcher AA, Narhi LO, Hale C, Marasco J, Delaney J, Gleason T, Philo JS and Katta $V$ et al.. (1998) Biochemical, biophysical, and pharmacological characterization of bacterially expressed human agouti-related protein. Biochemistry 37: 16041-52 [PMID:9819197]

87. Sawyer TK, Sanfilippo PJ, Hruby VJ, Engel MH, Heward CB, Burnett JB and Hadley ME. (1980) 4Norleucine, 7-D-phenylalanine-alpha-melanocyte-stimulating hormone: a highly potent alpha-melanotropin with ultralong biological activity. Proc. Natl. Acad. Sci. U.S.A. 77: 5754-8 [PMID:6777774]

88. Schimmer BP, Kwan WK, Tsao J and Qiu R. (1995) Adrenocorticotropin-resistant mutants of the Y1 adrenal cell line fail to express the adrenocorticotropin receptor. J. Cell. Physiol. 163: 164-71 [PMID:7896893]

89. Schioth HB, Muceniece R, Wikberg JE and Chhajlani V. (1995) Characterisation of melanocortin receptor subtypes by radioligand binding analysis. Eur J Pharmacol 288: 311-317 [PMID:7774675]

90. Schiöth HB. (2001) The physiological role of melanocortin receptors. Vitam. Horm. 63: 195-232 [PMID:11358115]

91. Schiöth HB, Haitina T, Ling MK, Ringholm A, Fredriksson R, Cerdá-Reverter JM and Klovins J. (2005) Evolutionary conservation of the structural, pharmacological, and genomic characteristics of the melanocortin receptor subtypes. Peptides 26: 1886-900 [PMID:15985310]

92. Schiöth HB, Muceniece R, Mutulis F, Bouifrouri AA, Mutule I and Wikberg JE. (1999) Further pharmacological characterization of the selective melanocortin 4 receptor antagonist HS014: comparison with SHU9119. Neuropeptides 33: 191-6 [PMID:10657491]

93. Schiöth HB, Muceniece R and Wikberg JE. (1996) Characterisation of the melanocortin 4 receptor by radioligand binding. Pharmacol. Toxicol. 79: 161-5 [PMID:8884876]

94. Schiöth HB, Muceniece R, Wikberg JE and Szardenings M. (1996) Alternative translation initiation codon for the human melanocortin MC3 receptor does not affect the ligand binding. Eur. J. Pharmacol. 314: 381-4 [PMID:8957262]

95. Schiöth HB, Mutulis F, Muceniece R, Prusis P and Wikberg JE. (1998) Discovery of novel melanocortin4 receptor selective MSH analogues. Br. J. Pharmacol. 124: 75-82 [PMID:9630346]

96. Sebhat IK, Martin WJ, Ye Z, Barakat K, Mosley RT, Johnston DB, Bakshi R, Palucki B, Weinberg DH, MacNeil T, Kalyani RN, Tang R, Stearns RA, Miller RR, Tamvakopoulos C, Strack AM, McGowan E, Cashen DE, Drisko JE, Hom GJ, Howard AD, Maclntyre DE, van der Ploeg LH, Patchett AA and Nargund RP. (2002) Design and pharmacology of $\mathrm{N}$-[(3R)-1,2,3,4-tetrahydroisoquinolinium- 3-ylcarbonyl]-(1R)-1-(4chlorobenzyl)- 2-[4-cyclohexyl-4-(1H-1,2,4-triazol- 1-ylmethyl)piperidin-1-yl]-2-oxoethylamine (1), a potent, selective, melanocortin subtype-4 receptor agonist. J. Med. Chem. 45: 4589-4593 [PMID:12361385]

97. Serova LI, Laukova M, Alaluf LG and Sabban EL. (2013) Intranasal infusion of melanocortin receptor four (MC4R) antagonist to rats ameliorates development of depression and anxiety related symptoms induced by single prolonged stress. Behav. Brain Res. 250: 139-47 [PMID:23680165]

98. Shen Y, Fu WY, Cheng EY, Fu AK and Ip NY. (2013) Melanocortin-4 receptor regulates hippocampal synaptic plasticity through a protein kinase A-dependent mechanism. J. Neurosci. 33: 464-72 [PMID:23303927]

99. Shutter JR, Graham M, Kinsey AC, Scully S, Lüthy R and Stark KL. (1997) Hypothalamic expression of ART, a novel gene related to agouti, is up-regulated in obese and diabetic mutant mice. Genes Dev. 11: 593-602 [PMID:9119224]

100. Skuladottir GV, Jonsson L, Skarphedinsson JO, Mutulis F, Muceniece R, Raine A, Mutule I, Helgason J, 
Prusis $\mathrm{P}$ and Wikberg JE et al.. (1999) Long term orexigenic effect of a novel melanocortin 4 receptor selective antagonist. Br. J. Pharmacol. 126: 27-34 [PMID:10051117]

101. Slominski A, Ermak $G$ and Mihm M. (1996) ACTH receptor, CYP11A1, CYP17 and CYP21A2 genes are expressed in skin. J. Clin. Endocrinol. Metab. 81: 2746-9 [PMID:8675607]

102. Smith Al and Funder JW. (1988) Proopiomelanocortin processing in the pituitary, central nervous system, and peripheral tissues. Endocr. Rev. 9: 159-179 [PMID:3286233]

103. Spaccapelo L, Bitto A, Galantucci M, Ottani A, Irrera N, Minutoli L, Altavilla D, Novellino E, Grieco P and Zaffe $\mathrm{D}$ et al.. (2011) Melanocortin $\mathrm{MC}_{4}$ receptor agonists counteract late inflammatory and apoptotic responses and improve neuronal functionality after cerebral ischemia. Eur. J. Pharmacol. 670: 479-86 [PMID:21946115]

104. Star RA, Rajora N, Huang J, Stock RC, Catania A and Lipton JM. (1995) Evidence of autocrine modulation of macrophage nitric oxide synthase by alpha-melanocyte-stimulating hormone. Proc. Natl. Acad. Sci. U.S.A. 92: 8016-20 [PMID:7544012]

105. Swords FM, Baig A, Malchoff DM, Malchoff CD, Thorner MO, King PJ, Hunyady L and Clark AJ. (2002) Impaired desensitization of a mutant adrenocorticotropin receptor associated with apparent constitutive activity. Mol. Endocrinol. 16: 2746-53 [PMID:12456795]

106. Szardenings M, Muceniece R, Mutule I, Mutulis F and Wikberg JE. (2000) New highly specific agonistic peptides for human melanocortin MC(1) receptor. Peptides 21: 239-43 [PMID:10764951]

107. Tan CP, McKee KK, Weinberg DH, MacNeil T, Palyha OC, Feighner SD, Hreniuk DL, Van Der Ploeg LH, MacNeil DJ and Howard AD. (1999) Molecular analysis of a new splice variant of the human melanocortin1 receptor. FEBS Lett. 451: 137-41 [PMID:10371153]

108. Tao YX. (2010) The melanocortin-4 receptor: physiology, pharmacology, and pathophysiology. Endocr. Rev. 31: 506-43 [PMID:20190196]

109. Vaisse C, Clement K, Durand E, Hercberg S, Guy-Grand B and Froguel P. (2000) Melanocortin-4 receptor mutations are a frequent and heterogeneous cause of morbid obesity. J. Clin. Invest. 106: 253-62 [PMID:10903341]

110. Valverde P, Healy E, Jackson I, Rees JL and Thody AJ. (1995) Variants of the melanocyte-stimulating hormone receptor gene are associated with red hair and fair skin in humans. Nat. Genet. 11: 328-30 [PMID:7581459]

111. van der Klaauw A, Keogh J, Henning E, Stephenson C, Trowse VM, Fletcher P and Faroogi S. (2015) Role of melanocortin signalling in the preference for dietary macronutrients in human beings. Lancet $\mathbf{3 8 5}$ Suppl 1: S12 [PMID:26312834]

112. van der Kraan M, Adan RA, Entwistle ML, Gispen WH, Burbach JP and Tatro JB. (1998) Expression of melanocortin- 5 receptor in secretory epithelia supports a functional role in exocrine and endocrine glands. Endocrinology 139: 2348-55 [PMID:9564844]

113. Van der Ploeg LH, Martin WJ, Howard AD, Nargund RP, Austin CP, Guan X, Drisko J, Cashen D, Sebhat I, Patchett AA, Figueroa DJ, DiLella AG, Connolly BM, Weinberg DH, Tan CP, Palyha OC, Pong SS, MacNeil T, Rosenblum C, Vongs A, Tang R, Yu H, Sailer AW, Fong TM, Huang C, Tota MR, Chang RS, Stearns R, Tamvakopoulos C, Christ G, Drazen DL, Spar BD, Nelson RJ and Maclntyre DE. (2002) A role for the melanocortin 4 receptor in sexual function. Proc Natl Acad Sci U S A.99: 11381-11386 [PMID:12172010]

114. Västermark A and Schiöth HB. (2011) The early origin of melanocortin receptors, agouti-related peptide, agouti signalling peptide, and melanocortin receptor-accessory proteins, with emphasis on pufferfishes, elephant shark, lampreys, and amphioxus. Eur. J. Pharmacol. 660: 61-9 [PMID:21208605]

115. Wachira SJ, Hughes-Darden CA, Taylor CV, Ochillo R and Robinson TJ. (2003) Evidence for the interaction of protein kinase $C$ and melanocortin 3-receptor signaling pathways. Neuropeptides 37: 201-10 [PMID:12906838]

116. Wardlaw SL. (2011) Hypothalamic proopiomelanocortin processing and the regulation of energy balance. Eur. J. Pharmacol. 660: 213-9 [PMID:21208604]

117. Wikberg JE. (1999) Melanocortin receptors: perspectives for novel drugs. Eur. J. Pharmacol. 375: 295-310 
[PMID:10443584]

118. Wikberg JE and Mutulis F. (2008) Targeting melanocortin receptors: an approach to treat weight disorders and sexual dysfunction. Nat Rev Drug Discov 7: 307-23 [PMID:18323849]

119. Xia $Y$ and Wikberg JE. (1996) Localization of ACTH receptor mRNA by in situ hybridization in mouse adrenal gland. Cell Tissue Res. 286: 63-8 [PMID:8781213]

120. Yang Y. (2011) Structure, function and regulation of the melanocortin receptors.Eur. J. Pharmacol. 660: 125-30 [PMID:21208602]

121. Yang YK, Dickinson C, Lai YM, Li JY and Gantz I. (2001) Functional properties of an agouti signaling protein variant and characteristics of its cognate radioligand. Am. J. Physiol. Regul. Integr. Comp. Physiol. 281: R1877-86 [PMID:11705773]

122. Yang YK, Fong TM, Dickinson CJ, Mao C, Li JY, Tota MR, Mosley R, Van Der Ploeg LH and Gantz I. (2000) Molecular determinants of ligand binding to the human melanocortin-4 receptor. Biochemistry 39 : 14900-11 [PMID:11101306]

123. Yang YK, Ollmann MM, Wilson BD, Dickinson C, Yamada T, Barsh GS and Gantz I. (1997) Effects of recombinant agouti-signaling protein on melanocortin action. Mol. Endocrinol. 11: 274-80 [PMID:9058374]

124. Yang YK, Thompson DA, Dickinson CJ, Wilken J, Barsh GS, Kent SB and Gantz I. (1999) Characterization of Agouti-related protein binding to melanocortin receptors. Mol. Endocrinol. 13: 148-55 [PMID:9892020]

125. Ye Z, Guo L, Barakat KJ, Pollard PG, Palucki BL, Sebhat IK, Bakshi RK, Tang R, Kalyani RN, Vongs A, Chen AS, Chen HY, Rosenblum Cl, MacNeil T, Weinberg DH, Peng Q, Tamvakopoulos C, Miller RR, Stearns RA, Cashen DE, Martin WJ, Metzger JM, Strack AM, Maclntyre DE, Van der Ploeg LH, Patchett AA, Wyvratt MJ and Nargund RP. (2005) Discovery and activity of (1R,4S,6R)-N-[(1R)-2-[4-cyclohexyl-4[[(1,1-dimethylethyl)amino]carbonyl]- 1-piperidinyl]-1-[(4-fluorophenyl)methyl]-2-oxoethyl]-2-methyl-2azabicycl o[2.2.2]octane-6-carboxamide (3, RY764), a potent and selective melanocortin subtype-4 receptor agonist. Bioorg Med Chem Lett 15: 3501-3505 [PMID:15982875] 